\title{
Fake Tax Transparency? Leaks and Taxpayer Rights
}

\section{The ROLE OF INTERNATIONAL TAX TRANSPARENCY}

International tax transparency is associated with the elimination of obstacles to the cross-border sharing of relevant information concerning a taxpayer or group of taxpayers. The current international standard promotes automatic exchange of information ${ }^{1}$ and rejects the possibility for states to decline to supply information solely because this information is held by a bank, other financial institution, nominee or person acting in an agency or a fiduciary capacity, or because it relates to ownership interests in a person. ${ }^{2}$

Tax transparency requires the exchange of information between tax administrations, and permits the use of different methods in this regard, namely: exchange of information upon request, if it is of foreseeable relevance to the enforcement of tax treaties or domestic tax law of the requesting state; automatic exchange of information, which implies the periodic supply of information by a source state concerning residents in another state, and mainly targeted at financial account information; and spontaneous exchange of information, where there are grounds to suppose that there may be a loss of tax in the other state or that there should be some adjustment of taxes in that other state due to tax savings in the reporting state. ${ }^{3}$ The aforementioned methods may be combined and the contracting States may use other techniques such as simultaneous examinations, tax exams abroad and industry-wide exchange of information. ${ }^{4}$

\section{The efFicacy OF tAX LeAKS}

In spite of all the bilateral and multilateral measures on tax transparency that have been taken and expanded since 2009, the media leaks have revived the discussion of tax havens and non-cooperative jurisdictions, and of the efficacy of international measures aiming to dismantle the opacity in those jurisdictions and the related schemes. For example the leaked financial documents that comprise the Paradise Papers expose how public figures, multinationals and high-net worth individuals can easily transfer their income to non-cooperative jurisdictions.

The Guardian described the Paradise Papers as a special investigation by the Guardian and ninety-five media partners worldwide into a leak of 13.4 million files from two offshore service providers and the company registries of nineteen tax havens. These files reveal the offshore financial affairs of some of the world's largest multinational companies and richest individuals, and set out the myriad ways in which tax can be avoided using artificial structures. ${ }^{5}$

In the Paradise Papers, the focus is on the Isle of Man, a jurisdiction that is considered to be compliant based on the Global Forum review criteria: ${ }^{6}$

The leak of more than $13 \mathrm{~m}$ documents from offshore law firms and registers have exposed in vivid detail the mechanics of a normally invisible and secretive industry an industry that regards the Isle of Man as one of its global headquarters.

(...) Manx companies have been used to transfer Kremlincontrolled state funds into Twitter and Facebook; they have obscured the financial connections between two Premier

\section{Notes}

The international standard, which was developed by the OECD in cooperation with non-OECD countries and which was endorsed by the G20 Finance Ministers at their Berlin Meeting in 2004 and by the UN Committee of Experts on International Cooperation in Tax at its Oct. 2008 Meeting, requires the exchange of information on request in all tax matters for the administration and enforcement of domestic tax law without regard to a domestic tax interest requirement or bank secrecy for tax purposes: OECD, Tax Co-operation 2009: Towards a Level Playing Field 8 (2009). The situation has evolved: on 19 Apr. 2013, the G20 Finance Ministers and Central Bank Governors endorsed automatic exchange as the expected new standard and on 20 July they endorsed the OECD proposals for a global model for multilateral and bilateral automatic exchange of information. See A. P. Dourado, Article 26, in Klaus Vogel Commentary on OECD Model Convention (E. Reimer \& A. Rust eds, Kluwer 2013), at fn. 4.

2 Art. 26(5) of the OECD Model Convention and UN Model Convention; Art. 1 of the 2002 OECD Model Agreement on Exchange of Information on Tax Matters (MA on TIEAs)) and its 2005 Comm.; 2010 Prot. to the Council of Europe/OECD Convention on Mutual Administrative Tax Matters. EU Mutual Assistance Directive: Council Directive 2011/16/EU of 15 Feb. 2011 on administrative cooperation in the field of taxation and repealing Directive 77/799/EU, OJ L 64/1 (2011)], Art. 18(2).

Art. 26 of the OECD Model Convention, Comm. 9 (as amended on 15 July 2014).

Id., Comm. 9.1

J. Garside, After Successive Offshore Scandals, Are There Signs of Change in Isle of Man?, Guardian (14 Nov. 2017).

Global Forum on Transparency and Exchange of information for Tax Purposes, 13 http://www.oecd.org/tax/transparency/GFratings.pdf (accessed 20 Nov. 2017). 
League football club owners; and they have been used to issue $\$ 1 \mathrm{bn}(£ 764 \mathrm{~m})$ of tax refunds to wealthy private jet owners (...)

It's an island where hundreds of 'straw' men and women will, for a small fee, stand in as the nominee directors and shareholders of shell companies - a legal, if increasingly dubious way, for the real owners of companies to obscure their real identities.

Pity the island's chief constable, Gary Roberts. In May, he sounded the alarm in his annual report. He described financial crime as a 'genuinely strategic threat' to the future of the island. ${ }^{7}$

It is reasonable to assume that, similarly to previous leaks, the tax administrations of the residence states of the beneficial owners were unaware of many of those relevant cases.

\section{THE EFFICACY OF THE INTERNATIONAL TAX STANDARDS}

The recent leaks highlight the role of artificial structures and the difficulty in detecting them. Mere lists of names revealed by the several leaks and discovered by the international consortium of journalists are not, in and of themselves, proof of tax evasion, but nevertheless raise high suspicion of such behaviour or, at least, aggressive tax planning. No doubt, the fact that such leaks still occur can be interpreted as a failure of the current legal framework, ${ }^{8}$ and serve as a means of pressure for the G20 and the Global Forum to make that framework more efficient.

On the other hand, it is difficult to argue that international tax coordination on tax transparency could move faster. Since 2009, the internationally agreed standard on exchange of information has changed from exchange of information on request to automatic and multilateral exchange of information. ${ }^{9}$ So far, automatic exchange of information applies to financial account information under both the OECD and EU legal instruments, as well as under US Foreign Account tax Compliance Act (FATCA). The Standard for Automatic Exchange of Financial Account Information in Tax Matters was published by the OECD on 21 July 2014 and includes the text of the Model Competent Authority Agreement, the Common Reporting Standard and the Commentaries thereon, as well as guidance on relevant technical solutions related to the IT aspects of data safeguards, confidentiality and encryption for the secure transmission of information under the Common Reporting Standard. ${ }^{10}$ Automatic exchange of information in the EU may apply in some years to (all) other categories of income which is appropriate for a territory - the EU territory as defined in Article 52 of the EU Treaty - where no obstacles can be raised to movements that go beyond capital and cover workers, establishment, services, goods and citizens.

Nevertheless, from a worldwide perspective, automatic exchange of information on financial accounts and identification of the beneficial owners of accounts is the core target of transparency, as all other activities - whether licit or illicit - involve movements of capital that can be hidden in opaque structures in more appealing tax jurisdictions.

The above-mentioned scandals revealing the failure of the current legal framework on tax transparency can be interpreted differently. Leaks reveal the dimension of the above-mentioned 'normally invisible and secretive industry' of hidden wealth. However, the current international standard on exchange of information also produces results, even if at a slower pace. Suspicions of tax evasion connected with money laundering and corruption schemes have been discovered by tax authorities in connection with criminal investigators and public prosecutors.

Both the leaks and the legal framework will lead to a common goal: to deter taxpayers from investing in tax havens, due to the increasing high risk of their hidden wealth being revealed.

However, the international consortium of journalists is mainly focusing on the inefficacy - or even fallacy - of the international standard, as well as its adoption and implementation, and is not aware that the change of paradigm has been accommodated by both tax authorities and courts.

\section{Recent court decisions on EXchange OF INFORMATION AND TAXPAYER RIGHTS}

The change of paradigm has reached the courts in several jurisdictions, and notably in jurisdictions that were traditionally non-cooperative. For example in a decision of 13 February 2017, ${ }^{11}$ the Swiss Federal Supreme Court held that as regards the exchange of information for transfer pricing purposes, the requirement of 'foreseeable relevance' cannot constitute an obstacle to supplying copies of financial statements, information on the number of employees and their functions; on the

\section{Notes}

Garside, supra n. 5

Q Questioning the efficacy of the Global Forum and exchange of information, see e.g. J. Johannesen, Taxing Hidden Wealth: Lessons for Policy Making, EUI Working Papers, 25 RSCAS (2012); N. Johannesen \& G. Zucman, The End of Bank Secrecy? An Evaluation of the G20 Tax Haven Crackdown, WP No. 2012-04, Paris School of Economics; T. Ronfeldt, Tax Havens and Tax Shelters: The Hidden Money, 43 Intertax 418 (2015).

9 OECD, Standard for Automatic Exchange of Financial Account Information: Common Reporting Standard (13 Feb. 2014); id., Standard for Automatic Exchange of Financial Account Information in Tax Matters.

$10 \mathrm{~J}$. Mosquera Valderrama, Legitimacy and the Making of International Tax Law: The Challenges of Multilateralism, 7 World Tax J. 3 (2015); X. Oberson, International Exchange of Information in Tax Matters, Towards Global Transparency (2015).

11 CH: Bger, 13 Feb. 2017, 2C_411/2016. 
business premises; on taxable profits; or on the tax liability in Switzerland. According to the Court, the requested state must rely on the assessment of relevance in the requesting state, based on the principle of good faith. ${ }^{12}$

In a decision of 12 September $2016,{ }^{13}$ the Swiss Federal Supreme Court interpreted the concept of foreseeable relevance under Article 26(1) of the Switzerland-Netherlands tax treaty. The Dutch tax authorities sought information on all UBS clients resident in the Netherlands that did not comply with the UBS request to provide evidence regarding their tax compliance. The Court relied on a mutual agreement in the Protocol of 26 February 2010 which clarified that persons under investigation may also be identified by means other than their name and address. The Court further emphasized that the purpose of the tax treaty is to provide for exchange of information in tax matters to the broadest extent possible. ${ }^{14}$

In a decision of 22 January 2015, ${ }^{15}$ the Singapore Court of Appeal held that it should not substantively review the requirements for exchange of information, such as the foreseeable relevance of the requested information and whether the information could have been obtained under the law of the requesting state. Moreover, relying on the Commentary on Article 26 of the OECD Model (paragraph 10.3), the Court concluded that where a treaty does not limit the temporal scope of the information to be exchanged, Article 26 allows for exchange of information covering periods both before and after the treaty entered into force.

In the above-mentioned cases, the courts seem eager to follow the international standard on exchange of information, overlooking the legal conditions and in some cases jeopardizing taxpayer rights. ${ }^{16}$

This case law illustrates that the efficiency of exchange of information is one of the main concerns, especially where courts in the requested state do not assess whether the condition of 'foreseeable relevance' is met. Instead, in these cases, the courts of the requested state rely on the good faith of the requesting state.

This new trend, in policy and interpretation of legal conditions, is a result of the international standard on automatic (and periodic) exchange of information on financial accounts. Automatic exchange of information is, by definition, incompatible with an assessment of 'foreseeable relevance' on a case-by-case basis. The same is true for multilateral exchange of information. There is a force of attraction effect: foreseeable relevance in exchange of information on request becomes irrelevant, because it is irrelevant under automatic and multilateral exchange of information.

Leaks in the press referred to above ignore the enhanced international tax cooperation where the international standards, tax authorities, financial institutions and domestic courts are engaged in achieving tax transparency.

However, the fact that it is not verified whether the condition of foreseeable relevance is met may lead to a significant infringement of taxpayer rights (for example false information may be exchanged or the confidentiality of data may be at risk). The same is true in respect of an exchange of information with retroactive effect.

The exchange of information with retroactive effect has a sanction character, is of dubious international tax justice, and is hardly compatible with the rule of law and with the principle of proportionality. In fact, until recently, many OECD and EU jurisdictions protected bank secrecy as a constitutional right to privacy. The international standard that denies the possibility for states to decline to supply information solely because such information is held by a bank or other financial institution, only goes back to 2002 at the OECD (Article 1 of the 2002 Model Agreement on Tax Information Exchange Agreements (TIEAs)) and 2013 in the EU (entry into force of the Mutual Assistance Directive (commonly referred to as DAC 1)).

However, the jurisprudence is not homogeneous. Other decisions have barred the exchange of information in the case of illicitly obtained data; deemed it to be unconstitutional to make country-by-country reports available to the public; and recognized liability for providing false information.

In a decision of 17 March $2017,{ }^{17}$ the Swiss Federal Supreme Court held that information cannot be exchanged where a request by the French tax authorities is based on illegally obtained information. ${ }^{18}$

France adopted public country-by-country reporting on 8 November 2016 as part of its law concerning transparency, fight against corruption and modernization of the economy. ${ }^{19}$ On 8 December 2016, the French Council of

\section{Notes}

12 Similarly CH: Bger, 13 Feb. 2017, 2C_954/2015.

13 CH: Bger, 12 Sept. 2016, 2C_276/2016.

14 V. Wöhrer: Dourado, supra n. 1, update of 20 Sept. 2016 on Art. 26 OECD MC, para. 187.

15 SG: CA, 22 Jan. 2015, ABU v. Comptroller of Income Tax, Civil Appeal 150 (2015) SGCA 4. See V. Wöhrer: Dourado, supra n. 1, update of 23 Feb. 2016 on Art. 26 OECD MC, paras 161, 216, 225.

16 On exchange of information and the taxpayers' rights, see inter alia Dourado, supra n. 1, paras 208-210, 304-305; Exchange of Information and Validity of Global Standards in Tax Law: Abstractionism and Expressionism or Where the Truth Lies, EUI Working Paper RSCAS 2013/11, at 5-6.General Report, The Practical Protection of Taxpayers' Fundamental Rights vol. 100B, 21 (P. Pistone \& P. Baker eds, IFA Cahiers 2015); J. M. Calderón Carrero \& A. Q. Seara, The Taxpayer's Right of Defence in Cross-Border Exchange-ofInformation Procedures, 68 Bull. Int'l Tax'n 498 (2014); A. Cockfield, Protecting Taxpayer Privacy Rights Under Enhanced Cross-Border Tax Information Exchange: Toward a Multilateral Taxpayer Bill of Rights, 42 U. B.C. L. Rev. 419 (2010), M. G. De Flora, Protection of the Taxpayer in the Information Exchange Procedure, 44 Intertax 447 (2017).

17 CH: Bger, 17 Mar. 2017, 2C_1000/2015.

18 Wöhrer: Dourado, supra n. 1, update of 11 Apr. 2017 on Art. 26 OECD MC, para. 296. However, the German Constitutional Court held there was no prohibition in assessing proof if the data were obtained in an illegal or even criminal manner: BVerfG 9 Sep. 2010, 2 BvR 2101/09.

19 FR: Law 830 of 6 Nov. 2016 
State (Conseil d'État) held that making country-by-country reports available to the public interferes disproportionally with the freedom of enterprise and is thus unconstitutional. $^{20}$

In its decision on 11 February 2015 in the Aloe Vera case, ${ }^{21}$ the US District Court of Arizona dealt with the disclosure of taxpayer information under the US-Japan tax treaty and held that the treaty does not authorize the disclosure of false tax return information. The information was false because it was merely an estimate of potential for unreported income and subsequently appeared in the Japanese media.

Finally, data protection has been addressed by the Court of Justice of the European Union (ECJ) in several cases, including as regards the indiscriminate retention of data ${ }^{22}$ and the lack of a purpose limitation principle for data collection. $^{23}$ An adequate level of protection through its domestic law or international commitments is not addressed by the EU Mutual Assistance Directive (DAC 1), but is a condition for data transfer from Member States to third countries in Article 25 of the Data Protection Directive. ${ }^{24}$ The level of protection should be essentially equivalent to that guaranteed within the European Union. ${ }^{25}$

\section{TRANSPARENCY AND TAXPAYER RIGHTS AS AN INTERTWINED INTERNATIONAL STANDARD}

The media have not delved into the consequences of tax transparency and leaks in jurisdictions where informa- tion can be used by authoritarian regimes as a tool to harass opponents of the government or to abuse political power. ${ }^{26}$ Moreover, the media are not alert to the challenges that the transparency movement and pressure on international institutions are causing for taxpayer rights, including as regards: whether exchange of information is discussed and approved by national parliaments and whether it is implemented in a rule-of-law state; the necessity of data protection; the necessity of exchanging only reliable data; the question as to whether it is legitimate to use illicitly obtained data; the transfer of data; and the necessity to protect whistle-blowers. The Global Forum has not included the protection of taxpayer rights among its priorities. ${ }^{27}$

The rule of law in international coordination on tax transparency requires a two-pronged assessment, namely of the harm caused by (1) opaque structures and noncooperative jurisdictions to international tax justice and (2) insufficient protection of data and other taxpayer rights, as well as insufficient protection of whistleblowers.

The Global Forum should accept and acknowledge only those members that exchange information and respect taxpayer rights. A peer-review process oriented by the Global Forum should not only require an analysis of the legal framework and its implementation, but include the requirement of rule of law, where an independent and impartial judiciary plays a major role.

Ana Paula Dourado

\section{Notes}

20 Wöhrer: Dourado, supra n. 1, update of 23 Dec. 2016 on Art. 26 OECD MC, para. 340.

21 US: USDC D. Ariz., 11 Feb. 2015, Aloe Vera of America Incorporated et al. v. United States, Case CV-99-01794-PHX-JAT.

22 SE: ECJ, 21 Dec. 2016, Cases C-203/15 \& C-698/15, Tele2 Sverige, para. 127.

23 E.g. IE: ECJ, 8 Apr. 2014, Cases C-293/12 \& C-594/12, Digital Rights Ireland, para. 53.

24 EU Data Protection Directive: Directive 95/46/EC on the protection of individuals with regard to the processing of personal data and on the free movement of such data, OJ L281 (1995).

25 IE: ECJ, 5 Oct. 2015, Case C-362/14, Shrems, para. 73. See S. Moreno Gonzalez, The Automatic Exchange of Tax Information and the Protection of Personal Data in the European Union: Reflections on the Latest Jurisprudential and Normative Advances, 25 EC Tax Rev. 146 (2016); X. Huang, Ensuring Taxpayers' Rights in the Era of Automatic Exchange of Information - In the Light of Data Protection Rules and Cases in European Union, Intertax (2018), Issue 3 forthcoming.

26 See e.g. Tribunal Fédéral of 13 Aug. 2007, 1A.15/2007/col: The Swiss federal court rejected a request for exchange of information for criminal purposes in the Yukos case, on the basis that the information would be used for political persecution: "The totality of these elements bears out the suspicion that the penal procedure was therefore used for the purposes of the established power, in order to go after the class of rich "oligarchs" and to push aside potential or declared political adversaries. It follows that Mutual Assistance cannot be granted :'

27 Dourado, Exchange of Information and Validity of Global Standards ..., supra n. 16, at 5-6. 